AL IBTIDA: JURNAL PENDIDIKAN GURU MI (2017) VOL. 4(1): 119-128

DOI: http://dx.doi.org/10.24235/al.ibtida.snj.v4i1.1476

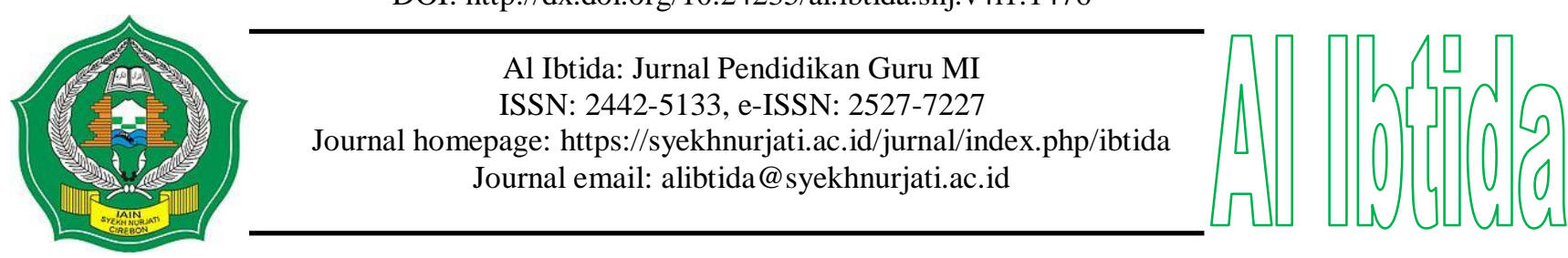

\title{
Pengembangan Media Utama (Ular Tangga Matematika) dalam Pemecahan Masalah MatematikaMateri Luas Keliling Bangun Datar Kelas III SD/MI
}

\author{
Sigit Widhi Atmoko* \\ *Jurusan Pendidikan Guru SekolahDasar, Fakultas Ilmu Pendidikan,Universitas PGRI Semarang \\ Email:sigitwidhiatmoko18@gmail.com \\ Fajar Cahyadi** \\ **Jurusan Pendidikan Guru SekolahDasar, Fakultas Ilmu Pendidikan,Universitas PGRI Semarang \\ Email:fajarcahyadi@upgris.ac.id \\ Ikha Listyarini*** \\ ***Jurusan Pendidikan Guru SekolahDasar, Fakultas Ilmu Pendidikan,Universitas PGRI Semarang \\ Email:ikhalistyarini@gmail.com
}

Received 13 April 2017; Received in revised form: 16 May 2017; Accepted 06 June 2017

Publish Online: 20 Juni 2017

\begin{abstract}
Abstrak
Landasan penelitian ini didasari dari adanya siswa yang masih kebingungan terhadap materi tentang bangun datar yaknitentang rumus luas dan keliling bangun persegi dan persegi panjang. Dari permasalahan tersebut tindak lanjut guru tentang permasalahan tersebut masih belum maksimal karena keterbatasan alat dan media untuk meningkatkan minat belajar siswa, sehingga guru masih menggunakan pembelajaran ceramah dan menggunakan LKS sebagai acuan belajar siswa. Penelitian ini bertujuan untuk menghasilkan media pembelajaran berupa UTAMA (Ular Tangga Matematika)dengan pokok bahasan keliling dan luas bangun datar untuk siswa kelas III sekolah dasar yang layak digunakan. Penelitian ini merupakan penelitian pengembangan (Research and Development)menurut Borg dan Gall namun dibatasi sampai uji coba produk terbatas. Subjek penelitian adalah 57 siswa kelas III SDN 1 Pungangan, SDN 2 Pungangan, SDN Larangan Kulon Wonosobo.Teknik pengumpulan data menggunakan observasi, wawancara, angket dan dokumentasi dengan teknikanalisis databerupa deskriptif kuantitatif dan deskriptif kualitatif. Hasil pengembangan iniberupa media UTAMA denganhasil penilaian akhir dari ahli media sebesar 95\% termasuk kategori sangat baik danhasil penilaian akhirdari ahli materi sebesar $90 \%$ termasuk kategori sangat baik. Hasil tes evaluasi siswa rata-rata sebesar 88,84.Hasil analisis tangggapan siswa terhadap media sebesar94,4\% dan pada angket keberterimaan media oleh guru sebesar 90\%. Hal ini menunjukan bahwa media UTAMA telah dinyatakan validdan layak digunakan dalam pembelajaran di sekolah dasar.
\end{abstract}

Kata kunci: pengembangan, media utama, pemecahan masalah matematika. 


\begin{abstract}
The study is based on the existence of students who are still confused about the material about the wake flat about the formula area and circumference of building square and rectangle.From the problems above, teachers' follow-up of the problems still had not maximal due to limitations of tools and medias to increase students interest, so that teachers still used communicative learning and worksheets as students references. This study aimed to produce teaching media in the form Snakes and Ladders Mathematics with the subject were areas and circumferences of two-dimentional figure for third grade of elementary school which the teaching media proper to used. This research is a development (Research and Development) by Borg and Gall but it was restricted to the limited product trials. The subjects of the study were 57 students of third grade in SDN 1 Pungangan, SDN 2 Pungangan, SDN Larangan Kulon Wonosobo. The data collection techniques used observations, interviews, questioners and documentations which the data analysis techniques in the form of descriptive quantitative and descriptive qualitative. The result of this development was Snakes and Ladders Mathematics with the results of the final assessment from media experts was $95 \%$ included in the category of very good results and the result of the final assessment from media experts was $90 \%$ included in the category of very good results, the results of evaluation of students' test averaged of 88.84. The analysis results of students' response to the media was $94.4 \%$ and in the media acceptance questionnaire by teachers was $90 \%$, this showed that Snakes and Ladders Mathematics as teaching media had been declared valid and proper to used in learning at elementary school.
\end{abstract}

Keywords: the development, snakes and ladders media, mathematical problem solving

\title{
PENDAHULUAN
}

Matematika merupakan suatu ilmu yang mendasari perkembangan teknologi modern, mempunyai peran penting dalam berbagai disiplin ilmu dan memajukan daya pikir manusia (Depdiknas, 2006: 390). Matematika perlu diberikan kepada semua siswa mulai dari sekolah dasar untuk membekali siswa agar memiliki kemampuan berpikir logis, analisis, sistematis, kritis dan kreatif serta kemampuan bekerjasama. Selain itu dimaksudkan pula untuk mengembangkan kemampuan menggunakan matematika dalam pemecahan masalah dan mengomunikasikan ideide atau gagasan. Pembelajaran matematika di sekolah dasar merupakan dasar bagi siswa untuk menerima konsep-konsep matematika secara benar. Oleh karena itu pembelajaran matematika di sekolah dasar harus berjalan optimal agar mencapai tujuan pembelajaran. Salah satu cara untuk mencapai keberhasilan tersebut adalah dengan menerapkan model, metode, dan strategi pembelajaran juga harus dimaksimalkan, selain itu kemampuan guru dalam merancang dan menerapkan media pembelajaran merupakan kunci dari keberhasilan proses pembelajaran.

Berdasarkan penjelasan di atas, media yang sesuai dengan karakteristik siswa sekolah dasar yaitu sebuah media yang bisa dikombinasikan dengan permainan. Menurut (Arsyad, 2014: 29),"media pembelajaran dapat meningkatkan dan mengarahkan perhatian anak sehingga dapat menimbulkan motivasi belajar, interaksi yang lebih langsung antara siswa dan lingkunganya, dan 
kemungkinan siswa untuk belajar mandiri sesuai dengan kemampuan dan minatnya". Pemilihan jenis media ini berdasarkan karakteristik siswa yang cenderung suka bermain dan aktif, salah satu media yang cocok dengan karakteristik siswa ini adalah media permainan. Melalui media permainan diharapkan siswa dapat memperoleh kesenangan tanpa adanya paksaan, sehingga siswa akan merasa senang untuk melakukan dan terhibur. Selain itu permainan juga memberikan pengalaman nyata dan dapat membantu siswa untuk meningkatkan kemampuan kognitif.

Berdasarkan hasil wawancara yang telah dilakukan pada proses belajar mengajar di kelas III mata pelajaran matematika pada kompetensi dasar memecahkan masalah yang berhubungan dengan luas dan keliling, siswa terkadang bingung terhadap rumus luas dan keliling persegi panjang dan mengaplikasikan rumus untuk menghitung luas dan keliling persegi dan persegi panjang. Selain itu data yang diperoleh bahwa guru hanya mengandalkan papan tulis dan LKS sehingga pembelajaran kurang optimal yang menyebabkan hasil belajar peserta didik masih rendah dan siswa kurang aktif mengikuti proses belajar mengajar. Siswa masih susah dalam menghadapi soal cerita tentang luas persegi maupun persegi panjang, dan guru selama ini masih menggunakan papan tulis dan buku LKS sebagai acuan pembelajaran. Dari hasil wawancara terhadap guru kelas III bahwa siswa masih kebingungan terhadap rumus luas dan keliling bangun persegi persegi panjang dan menerapkan rumus untuk menghitung luas maupun keliling persegi dan persegi panjang. Dari permasalahan tersebut tindak lanjut guru tentang pernasalahan tersebut masih belum maksimal karena keterbatasan alat dan media untuk meningkatkan hasil belajar siswa, sehingga guru masih menggunakan pembelajaran ceramah dan menggunakan LKS sebagai acuan belajar siswa.

Berdasarkan permasalahan yang ada, maka perlu adanya media yang sesuai dengan karakteristik siswa untuk meningkatkan minat belajar siswa pada mata pelajaran matematika materi luas dan keliling persegi dan persegi panjang. Media yang dianggap sesuai dengan kondisi yang ada yaitu media permainan edukatif. Hal ini sesuai dengan siswa yang masih cenderung aktif dan suka bermain. Menurut Siswoyo (2015: 9), “Alat permainan edukatifdapat digunakan sebagai media belajar sambil bermain”. Berdasarkan pendapat tersebut, peneliti bermaksud mengembangkan media permainan edukatif berbentuk ular tangga agar memudahkan siswa dalam belajar matematika pada materi keliling dan luas bangun datar.

Permainan ular tangga adalah permainan papan yang dimainkan oleh dua orang atau lebih. Menurut Husna (2009: 145) mengatakan bahwa "ular tangga adalah permainan yang menggunakan dadu untuk menentukan berapa langkah yang harus di jalani bidak". Bentuk papan ular tangga berupa gambar kotak-kotak yang terdiri dari 10 baris dan 10 kolom dengan nomor 1100, serta bergambar ular tangga. Permainan ini diciptakan pada tahun 1870 dan tidak ada papan permainan standar dalam ular tangga, sehingga setiap orang dapat dapat menciptakan papan 
mereka sendiri dengan jumlah kotak, ular dan tangga yang berlainan. Permainan ular tangga pada umumnya yaitu permainan yang menggunakan dadu untuk menentukan berapa langkah yang harus di jalani bidak. Dalam permainan ular tanga ini mampu mengasah kesabaran, kejujuran, serta kerjasama antar anggta kelompok dalam menyelesaikan pertanyaan yang di berikan oleh guru.

Berdasarkan uraian di atas, yang dimaksud dengan media permainan UTAMA (Ular Tangga Matematika) ini merupakan hasil pengembangan dari permainan ular tangga yang dimodifikasi sedemikian rupa dengan menambah desain dan warna-warna yang menarik pada setiap petaknya, media ini menambahkan kartiu soal yang dikaitkan dengansetiap petak warna dan akan mengambil kartu dengan warna yang sama. Di dalam kartu terdapat soal untuk dijawab sesuai kerumitan soal, karna media ini tidak menggunakan dadu, maka siswa akan melangkah sesuai jumlah bintang pada kartu yang telah selesai dijawab. Permainan ular tangga ini dipilih karena mudah dimainkan oleh anak-anak. Selain itu juga ular tangga memiliki daya tarik tinggi bagi anak usia sekolah dasar. Penelitian sebelumnya mengenai ular tangga telah dilakukan oleh Agustin (2008), menunjukkan bahwa penggunaan permainan ular tangga dapat meningkatkan hasil belajar siswa.

Kelebihan UTAMA yang dikembangkan adalah bukan hanya sekedar permainan ular tangga yang biasanya menggunakan dadu sebagai keberuntungan seseorang untuk memenangkan permainan tersebut, namun ular tangga matematika ini dikemas sedemikian rupa dengan dilengkapi soal-soal pertanyaan tentang pemecahan masalah luas dan keliling bangun persegi serta persegi panjang, diharapkan dengan ular tangga matematika ini dapat meningkatkan minat belajar siswa.

Berdasarkan permasalahan dan hasil pemaparan di atas, maka peneliti merasa perlu mengembangkan media permainan edukatif berupa media permainan ular tangga matematika pada materi pemecahan masalah luas dan keliling bangun datar kelas III yang layak digunakan dalam pembelajaran matematika di sekolah dasar.

\section{METODE PENELITIAN}

Dalam penelitian ini, metode penelitian yang digunakan adalah metode penelitian dan pengembangan (Research and Development). MenurutBorg and Gall (1983) dalam Sugiyono (2015: 407) 'metode penelitian dan pengembangan atau dalam bahasa Inggrisnya Research and Development adalah metode penelitian yang digunakan untuk menghasilkan produk tertentu dan menguji keefektifan produk tersebut'.

Penelitian ini dilakukan dari tanggal 7 November 2016 - 18 Februari 2017 dengan subjek penelitian adalah 57 siswa kelas III dan 3 Guru kelas III di SDN 1 Pungangan, SDN 2 
Pungangan, dan SDN Larangan Kulon Wonosobo. Penelitian awal dilakukan studi pendahuluan di 3 sekolah guna mengambil data awal penelitian terhadap penggunaan media dari siswa dan guru kelas III. Metode pengumpulan data yang digunakan berupa lembar wawancara, angket analisis kebutuhan siswa maupun guru, lembar validasi media dan materi, dan lembar tes evaluasi. Penelitian pengembangan ini menggunakan dua teknik analisis data yaitu analisis deskriptif kualitatif dan analisis deskriptif kuantitatif.

\section{HASIL DAN PEMBAHASAN}

Pengembangan media menurut Borg and Gall terdiri dari sepuluh langkah pengembangan, namun penelitian ini hanya berbatas sampai pada tahap ke-enam yaitu yakni (1) potensi dan masalah, (2) pengumpulan data, (3) desain produk, (4) validasi desain, (5) revisi desain dan (6) Ujicoba Produk.

Potensi dan masalah dengan melakukan studi pendahuluan untuk melihat potensi dan masalah pembelajaran dari 57 siswa kelas II dan 3 Guru kelas III di SDN 1 Pungangan, SDN 2 Pungangan, dan SDN Larangan Kulon Wonosobo. Pengumpulan data berupawawancara terhadap guru kelas III dan menyebarkan angket kebutuhan guru dan siswa kelas III terhadap media pembelajaran Matematika.

Berdasarkan wawancara dan angket kebutuhan kemudian dianalisis dan didapat hasil bahwa siswa masih kebingungan terhadap materi luas keliling bangun datar khususnya pada soal-soal cerita, terkadang siswa susah menganalisis soal dan menggunakan rumus yang benar, sehingga penghitungan hasil akhir siswa salah. Sedangkan dari hasil wawancara dengan guru,diidentifikasi bahwa guru masih belum menemukan cara yang tepat untuk mengatasi hal tersebut, dan juga penggunaan media masih kurang karena keterbatasan koleksi media.Adapun masukan dari guru yakni perlu adanya media edukatif, sehingga siswa akan lebih tertarik dalam mengikuti pembelajaran. Berdasarkan uraian tersebut, maka peneliti berinisiatif mengembangkan media ular tangga yang dikaitkan dengan materi pelajaran matematika.

Desain media UTAMA dilakukan dengan dengan menggunakan Corel Draw X7 dan merancang sedemikian rupa dengan desain yang menarik sehingga dapat menarik perhatian siswa. Media ini dilengkapi dengan kartu soal dengan 4 variasi warna, setiap warna-warna kartu nantinya akan di kaitkan dengan warna petakan media, kartu soal berisikan pokok pembelajaran matematika dalam materi pemecahan masalah luas dan keliling bangun datar di kelas III. Media ini juga tentunya mengubah beberapa aturan permainan. Pembuatan media UTAMA juga melihat tingkat ketahanan media, yakni menggunakan kayu dan triplek sehingga tidak mudah rusak. Media UTAMA di buat dengan ukuran $30 \mathrm{~cm}$ x $42 \mathrm{~cm}$, dan bisa dilipat sehingga menjadi ukuran $30 \mathrm{~cm}$ x $21 \mathrm{~cm}$ sehingga praktis dan dapat menyimpan komponen-komponen media. 
Pada tahap selanjutnya yaitu melakukan validasi oleh ahli materi maupun ahli media pembelajaran guna untuk mengetahui tingkat kevalidan media. Validasi materi dilakukan oleh Dosen PGSD dengan melalui 2 tahapan. tahap I mendapatkan jumlah skor persentase 84,2\% dengan kategori baik. Validator memberi saran dan masukan antara lain: a) diberi gambar yang menarik, b) penggunaan kata-kata yang lebih sederhana. Tahap II mendapatkan jumlah skor persentase $90 \%$ dengan kategori sangat baik dan dinyatakan media UTAMA valid diujicobakan dalam kelas penelitian.

Validasi media juga dilakukan oleh Dosen PGSD yang ahlli dalam bidang seni dan media dengan melalui 2 tahapan. tahap I mendapatkan jumlah skor persentase 92,5\% dengan kategori sangat baik. Validator memberi beberapa saran antara lain: a) media dilapisi plastik supaya tidak mudah rusak ketika terkena air, b) kartu diberikan wadah agar tidak tercecer. Tahap II mendapatkan jumlah skor persentase $95 \%$ dengan kategori sangat baik tanpa revisi dan dinyatakan media UTAMA valid diujicobakan dalam kelas penelitian.

Ujicoba terbatas penggunaan media UTAMA melibatkan57 siswa kelas III di SDN 1 Pungangan, SDN 2 Pungangan, dan SDN Larangan Kulon Wonosobo. Dari pengamatan yang dilakukan, siswa antusias menggunakan media UTAMA dan dapat mengerjakan setiap soal-soal dalam media. Setelah melakukan pembelajaran dengan media UTAMA, peneliti melakukan evaluasi pembelajaran dan memberikan angket tanggapan terhadap media untuk diisi oleh siswa untuk mengetahui tingkat keberterimaan media dalam pembelajaran. Berdasarkan tes evaluasi yang telah dilakukan,didapatkanrata-rata nilaisebesar 88,84.Inimenunjukkan bahwasiswamampumenangkapmateri yang diajarkandanmampumengerjakansoal-soal yang diberikan.Soal tes evaluasi berjumlah 15 soal yang diambil dari buku paket BSE yang biasa digunakan oleh siswa.

Pada tahap uji coba terbatas, selain memberikan tes evaluasi, peneliti juga memberikan angket tanggapan terhadap media untuk siswa dan guru. Tanggapan siswa mengenai media UTAMA (Ular Tangga Matematika) yaitu siswa menjadi lebih tertarik mengikuti pembelajaran matematika, dengan menggunakan media ini siswa lebih mudah memahami konsep keliling dan luas persegi dan persegi panjang yang diberikan oleh guru karena selama pembelajaran berlangsung siswa lebih sering berlatih dan mencoba mengerjakan soal-soal dalam media. Hasil angket tanggapan siswa mendapatkan persentase rata-rata sebesar 94,4\% sehingga media dapat dikatakan layak dan media dapat diterima siswa dalam pembelajaran matematika. Sedangkan padatanggapan guru mengenai media UTAMA (Ular Tangga Matematika), gurumerasa terbantu dalam pembelajaran, karena guru merasa termudahkan dalam menyampaikan materi luas dan keliling bangun persegi persegi panjang. Guru merasa siswa dapat menjadi lebih aktif pada proses kegiatan belajar mengajar di kelas. Selain itu guru juga akan terasa santai dalam 
pembelajaran, karena siswa dapat belajar dengan mandiri, guru hanya mengawasi. Angket tanggapan yang diberikan kepada guru kelas III tersebut kemudian dianalisis untuk mengetahui tingkat kepraktisanmedia sehingga menunjukkan persentase rata-rata sebesar $90 \%$. Hal ini menunjukkan bahwa media dapat dikatakan layak dan praktis untuk digunakan dalam pemebelajaran matematika di sekolah dasar.

Media UTAMA (Ular Tangga Matematika) mendapat respon yang baik oleh guru dan siswa. Guru merespon baik karena dengan adanya media UTAMA (Ular Tangga Matematika) mampu membantu guru dalam menyampaikan materi yang ada pada mata pelajaran matematika materi luas dan keliling bangun persegi persegi panjang. Respon baik juga ditunjukan siswa, yaitu siswa suka dengan media UTAMA (Ular Tangga Matematika)sebagai media bantu untuk belajar.Berdasarkan uraian di atas, maka dapat ditarik kesimpulan bahwa media UTAMA (Ular Tangga Matematika) dapat meningkatkan minat belajar siswa pada materi pemecahan masalah matematika.

Dalam pengembangannya, media UTAMA (Ular Tangga Matematika) ini telah disesuaikan dengan teori belajar siswa. Teori belajar yang mendukung dilakukannya penelitian ini adalah teori belajar bermakna (David Ausubel), teori belajar Connectionism (thorndhike) dan teori belajar Discovery Learning. Menurut Ausubel, belajar dapat diklasifikasikan ke dalam dua dimensi. Dimensi pertama berhubungan dengan cara informasi atau materi pelajaran yang disajikan pada peserta didik melalui penerimaan atau penemuan. Dimensi kedua menyangkut cara peserta didik untuk dapat mengaitkan informasi itu pada struktur kognitif yang telah ada. Struktur kognitif ialah fakta, konsep, dan generalisasi yang telah dipelajari dan diingat oleh peserta didik.

Dengan media pembelajaran UTAMA, peserta didik dapat lebih memahami konsep luas dan keliling persegi dan persegi panjang. Pada tingkatan pertama dalam belajar penerimaan yang menyajikan informasi itu dalam bentuk belajar mengharuskan peserta didik untuk menemukan sendiri sebagian materi. Pada tingkat kedua, peserta didik menghubungkan atau mengaitkan informasi itu pada pengetahuan yang berupa konsep, seperti pada media pembelajaran UTAMA, siswa akan selalu mengingat kembali materi yang telah dipelajari sebelumnya yang berkaitan dengan konsep luas dan keliling persegi dan persegi panjang. Dalam penggunaannya, media UTAMA memasuki tingkatan kedua dalam pembelajaran, siswa dapat mengaitkan struktur kognitifnya dengan permainan yang akan dilakukan. Selain itu, ketika memainkan media UTAMA siswa akan lebih mudah mengingat konsep luas dan keliling bangun datar karena secara tidak sadar siswa telah mengulang-ulang konsep yang telah diajarkan dengan mengerjakan berbagai soal secara berulang-ulang. Hal tersebut sesuai dengan teori belajar yang disampaikan oleh David Ausubel sebagai pembelajaran bermakna. 
Selain teori belajar bermakna dari David Ausubel, teori belajar Connectionism (thorndhike) merupakan pembentukan koneksi antara stimulus dan respon. Hubungan dengan media UTAMA yaitu dengan adanya media tersebut dapat adalah sebagai stimulus kepada siswa sehingga siswa memperoleh suatu respon yang yang positif. Media UTAMA juga berhasil menarik perhatian siswa dalam mengikuti pelajaran matematika khususnya dalam materi pemecahan masalah luas dan keliling bangun persegi dan persegi panjang untuk kelas III SD.

Sedangkan menurut Teori Discovery Learning dari Jerome S Bruner, menyatakan bahwaanak harus berperan secara aktif belajar di kelas, konsepnya adalah belajar dengan menemukan. Guru harus memberikan keleluasan kepada Siswa untuk menjadi pemecah masalah (problem Solver). Dengan media UTAMA siswa dapat belajar secara aktif mandiri dengan menemukan permasalahan soal, mengklasifikasi permasalahan soal, dan menggeneralisasikan untuk menenukan rumus luas dan keliling persegi, persegi panjang.

Dampak pengiring dalam menggunakan media UTAMA disusun secara sederhana yakni untuk mendidik siswa dalam hal: (1) mendapatkan variasi media dalam pembelajaran matematika sehingga memudahkan untuk memahami materi luas dan keliling bangun persegi dan persegi panjang, (2) melatih siswa untuk memiliki jiwa kompetisi, (3) mengembangkan rasa percaya diri tiap individu (4) menggabungkan 3 ranah pembelajaran, yakni kognitif, afektif, dan psikomotorik.

\section{SIMPULAN}

Penelitian ini menghasilkan sebuah media ular tangga matematika yang layak digunakan untuk pembelajaran matematika dalam materi pemecahan masalah matematika materi luas keliling bangun datar kelas III sekolah dasar. Media UTAMA ini dikembangkan menggunakan tahapan penelitian R\&D dengan model Borg and Gallhanya dibatasi sampai pada tahap keenam yaitu ujicoba terbatas. Media ular tangga ini hasil dari pengembangan sebuah permainan ular tangga dengan mendesain sedemikian rupa dan menambah kartu soal sebagai pokok dalam pembelajaran matematika materi pemecahan masalah luas dan keliling bangun datar. Kevalidan produk ini dapat dilihat dari hasil validasi dilihat sebagai berikut.

Hasil akhir dari validasi ahli materi mendapatkan persentase 90\% termasuk dalam kategori sangat baik. Validasi tersebut meliputi aspek materi dan penyajian yang digunakan dalam media permainan ular tangga matematika.Hasil akhir dari validasi ahli media mendapatkan persentase $95 \%$ termasuk dalam kategori sangat baik. Validasi tersebut meliputi aspek tampilan dan penggunaan yang sesuai dengan karakteristik penggunaan media permainan ular tangga matematika. 
Pada tahap uji coba terbatas, hasil tes evaluasi pembelajaranyang telah dilakukan, didapatkan rata-rata nilai sebesar 88,84 . Ini menunjukan bahwasiswamampumenangkapmateri yang diajarkandanmampumengerjakansoal-soal yang diberikan.Selain tes evaluasi, tanggapan siswaterhadap media mendapatkan persentase rata-rata sebesar 94,4\% termasuk dalam kategori sangat baik. Tanggapan guru juga mendapatkan skor persentasi 90\% teemasuk dalam kategori sangat baik. Hal ini menunjukan bahwa media UTAMA media dapat dikatakan layak dan praktis untuk pemebelajaran matematika di sekolah dasar. 


\section{DAFTAR PUSTAKA}

Agustina, Nanik. 2008. Permainan ular tangga meningkatkan hasil belajar siswa dalam pembelajaran bilangan bulat siswa kelas IV SDN Kebonagung 06 Pakisaji Malang. Skripsi. Malang: Universitas Negeri Malang.

Arsyad, Azhar. 2014. Media Pembelajaran. Jakarta: PT RajaGrafindo Persada.

Depdiknas. 2006. Standar Isi untuk Satuan Pendidikan Dasar dan Menengah. Jakarta: BNSP.

M. Husna, A. 2009. 100+ Permainan Tradisional Indonesia untuk Kreativitas, Ketangkasan, dan Keakraban. Yogyakarta: Penerbit Andi.

Siswoyo,Joko. 2015. Pengembangan Alat Permainan Edukatif Ular Tangga Matematika Pokok Bahasan Luas Bangun Datar Untuk Siswa Kelas V Sd Negeri 1 SinduadiMlati Sleman. Jurnal. Yogyakarta: UNY.

Sugiyono.2015. Metode Penelitian Pendidikan (Pendekatan kuantitatif, Kualitatif,dan R\&D). Bandung: Alfabeta. 